\title{
GREEN SKILLS: INNOVATION IN THE SUBJECT OF DESIGN AND TECHNOLOGY (D\&T)
}

\author{
Amarumi Alwi ${ }^{1}$, Arasinah Kamis ${ }^{2}$, Haryanti Mohd Affandi ${ }^{3}$, Faizal Amin Nur Yunus ${ }^{4}$ \\ and Ridzwan Che Rus ${ }^{5}$ \\ 1, 2, 5 Faculty of Technical and Vocational Education, Sultan Idris Education University, Malaysia \\ ${ }^{3}$ Faculty of Education, National University of Malaysia, Malaysia \\ ${ }^{4}$ Faculty of Technical and Vocational Education, University Tun Hussein Onn, Malaysia
}

\begin{abstract}
This study explores the innovation of disseminating green skills through the process of teaching and learning in order to develop environmental sustainability. Green skills need to be inculcated in the lives of children as they are the agents of sustainable development. This study investigates the elements of green skills applicable to the practice for the subject of design and technology in the primary schools, as a measure to protect and conserve the environment. By using a qualitative research design, excellent teachers for the subjects of living skills and design and technology (D\&T) were interviewed. The focus group method was used to collect data by using semi-structured questions. The findings show that these green skills elements can be instilled in the students: solid waste management, green practices and the concept of 3R (Reduce, Reuse and Recycle). It is proposed that the Ministry of Education could utilize the results of this study to draft the curriculum for the subject of design and technology, which in turn would facilitate the production of teaching modules and introduction of green skills elements among the primary school students. This would be a step in the right direction in preserving and conserving the environment.
\end{abstract}

Keywords: Green Skills, Sustainable Development, Innovation, Design and Technology

\section{Introduction}

Organization for Economic Co-operation and Development, (OECD), (2016) states that green skills are an ability, also known as technical skills, values and attitudes, needed in the workplace to develop or support the sustainability of social life, economic activity, and results of business, industry and community. Teenagers view green jobs as jobs that are not popular and of low status; therefore, they pay less attention to this concept of green skills (Cedefop, 2012). The concept of green skills should be incorporated in the learning process of young children because they will be the sustainable catalytic agent who will inherit the environment (Stuhmcke, 2012). Given the growing environmental problems, it is very crucial to create a generation fully aware of the importance of preserving the environment (SitiRohani, 2013).

Although environmental education has been implemented via the school curriculum for a long time, environmental awareness remains at a low level (Jamilah and Hasrina, 2011), (Shahromet al. 2015). According to Saravanan and Ahmad, (2013), students' knowledge of and concerns for the environment are still at a moderate level. These findings point to a sober situation: green practices in everyday life have not reached the level that would lead to a reduction of environmental problems. Education about sustainable environment was introduced in the education system to develop skills, knowledge, attitudes, awareness, understanding, value and commitment in solving environmental problems (Sola, 2014), (Meenakshi and Leela, 2014). The practice of implementing elements and skills pertaining to sustainable environment is still at a level not to be proud of (Hanifah, 2014).

Thus, green skills need to be incorporated into the subject of design and technology as an innovation element that could generate environmental sustainability; and integration of green skills in the curriculum of technical

Corresponding Author:Amarumi Alwi/amarumialwi@ymail.com

$3^{\text {rd }}$ International Conference on Education, 20-22 April 2017, Kuala Lumpur, Malaysia 
and vocational education is vital. Continuous attempts and efforts must be made to develop the potential of individuals in an integrated and holistic manner; these can be done by improving the education and public awareness regarding green skills, and encouraging widespread adoption of green technology is another method as well. This blends in well with one of the primary aims of the national education, which is to produce individuals who are harmonious and balanced in every aspect--emotionally, spiritually, intellectually, and physically, founded on firm belief in God (Siti Nor Syazwani et al. 2014). The focus of this research is to explore the elements of green skills that can be applied during the process of teaching and learning in design and technology in primary schools as a measure to protect and conserve the environment.

\section{Literature Review}

Education for sustainability development, or ESD in short, began in 2001. The design plan and the establishment of sustainable programs were implemented formally in the Malaysian education system through the primary and secondary schools in 2005. ESD is recognized through Sustainable School Environment Award Program in Malaysia (SLAAS), (2012). The practice of sustainability is an important agenda in making students more responsible for the Earth in the future, but a study by Siti Rohani, (2013) states that the attitude of the individual is one of the factors contributing to the environmental problems. Environmental problems are closely linked with people's lifestyles that emphasize economic development and material gain, while they disregard the importance of environmental stewardship. An estimated 25,000 tonnes per day of solid waste was generated in 2012, and the Department of National Solid Waste found that food waste constituted 45 per cent of the total 29,000 tonnes of solid waste generated in a single day in Malaysia. However, only $5 \%$ is recycled despite many ongoing recycling campaigns and recycling bins provided in certain places. This is a result of the lack of knowledge and skills in the solid waste management system, especially in waste separation (Festus and Ogoeggbunam, 2012), (Licy et al. 2013).

Solid Waste Management Policy, (2016) has been introduced to create a solid waste management system that is systematic, environmentally friendly, cost-effective, sustainable, and is socially accepted by the people who stress the preservation of the environment, the choice of technology that is affordable and guarantees public health. Hasnahet al. (2012) and Fahzy (2014) suggest three elements of 3R, which are Reuse, Reduce and Recycle as the first core in the solid waste management policy. 3R is also an element of skills that can be trained and deployed in students, starting with primary school education; aspects of the sustainable environment are taught through the curriculum as a measure to mitigate the effects of global warming and environmental pollution (Taylor et al. 2015). Pupils of the primary school today will grow up as adults in the next ten to twenty years. Therefore, they should be instructed while they are young so that they are aware of the negative impacts on life brought about by the undesirable events in life (Sharifah Zarina, 2014).

In the study of (Stuhmcke, 2014) the author suggests that knowledge of environmental sustainability could bring an impact if it is aligned with Trans formative Project-Approach. Teaching about the environment is more effective when students are taught in and about the environment as well as for the environment compared with the old approach of simply learning about the environment without involving any project. Environmental education focuses on students' perspective of the concepts and theories. This education entails students to be connected with flora and fauna, forest, mountain, beach or park to create an awareness of and involvement in the environment. Environmental education aims to encourage an ability to adopt lifestyles that are harmonious with the natural resources. Australian Education for Sustainability Alliance (AESA), (2014)also suggests the concept of about, in and for in education.

\section{Green Skills}

Green skills refer to the skills, values and attitudes needed by humans to support and build the sustainability and effectiveness of energy sources as one of the manifestations in the field of green technologies and knowledge 
required in the workplace (SLAAS, 2012), (McDonald et al. 2012). In a sustainable education, green skills are more focused on skills of maintaining and conserving the environment. International Centre for Technical and Vocational Education and Training (UNEVOC), (2012) states, that Green Technical Vocational Education and Training (TVET) covers education that enhances problem-solving skills in everyday life (life management skills), education in sustainable development in life and entrepreneurship training.

Green skills, better known as green practices in Malaysia, include skills related to measures in conserving the environment. On the other hand, green technology relates to the application, development of the products and equipment systems to protect the environment as well as minimize or decrease the negative impact of human activity Ministry of Energy, Technology and Water, Malaysia (Kettha), (2012). Meanwhile, the objective of Green Technology Policy is to provide direction and motivation for the people of Malaysia to continue enjoying good quality of life and a healthy environment.

According to Strietska-Ilina et al. (2011), green skills are knowledge, skills, values and attitudes needed in life for the growth and support of the creation of a community that has an efficient and sustainable management in managing available resources. Based on the study of (Pavlova and Huang, 2013), they concluded that elements of green skills should be included in technical and vocational education as an added value, so no harm would be done to the environment by people who are science and technology-sensitive, hardworking, law-abiding and with integrity, in the conducts of their everyday life. Users are suggested to be green by applying green skills in their daily lives as much as possible, starting with common practices such as bringing lunch to work instead of using polystyrene (Arasinahet al. 2016).

In (Ifegbesan, 2010) students in the secondary schools of Ogun State recognize the problem of waste in their schools, but very few waste management practices are in place. It was found that girls engage in activities to protect the environment, as they are more concerned about environmental problems. It was recommended by (Wong and Wan, 2008), (Karpiak and Baril, 2008), (Ifegbesan, 2010) to adopt the use of water, separating the waste and saving electricity. Study by (Corbonel et al.2015)shows that respondents believe the government should provide incentives and carry out promotions so that green practices will continuously be implemented such as lessening the use of Styrofoam or plastic containers that are not environmentally friendly, prohibiting the use of plastic bags and using own containers when buying food. His research also found that adoption of sustainable practices among students is at a low level because they are less exposed to green skills education.

\section{Design and Technology Subject (D\&T)}

Standard curriculum of design technology (D\&T) was enacted in 2014 with an emphasis on content and learning standards that need to be known, understood and mastered by students of the primary school years 4,5 and 6 . This subject provides the students with early exposure of basic skills in the fields of technical, technology agriculture, home science and cross-curricular elements such as information and communication technology (ICT), creativity and innovation and entrepreneurship foundation. The elements of standard curriculum of design technology (D\&T) are still retained in Integrated Primary School Curriculum, (KBSR). In addition, the curriculum also emphasizes the inculcation of moral values, work-it-yourself (Do-it-yourself, DIY), sensitivity towards surrounding issues and a positive attitude, while the schools carry out activities to produce students who are tech-savvy, creative and have entrepreneurial characteristics (Dokumen Standard Prestasi, (DKSP), 2014)

The subject of design and technology imparts appropriate lessons that can be applied to add values to our life in terms of green skills (Zuhair, 2015), (Cedefop, 2014). Green skills provided by the subject of design and technology serve to produce students who are competent, and hence, this subject should be part and parcel of the school curriculum (Arasinah et al.2016). By implementing the curriculum, a comprehensive approach can be utilized to train students who will grow up to appreciate and conserve the environment (Teoh, 2016). As suggested by (Taylor et al. 2015), a different approach is needed to teach students about green aspects; although 
environmental education has long been taught in school, students do not seem to exhibit good behavior towards the environment.

\section{Innovation}

Green skills are an innovation that can be incorporated into the subject of design and technology; this new element is skill-oriented as the subject emphasizes practical aspects in the teaching and learning process. Based on the definition of (Rogers, 2003), innovation is an idea, practice, or new projects that are considered by the individual or the person who undertakes such innovation. In the process of welcoming a new innovation, an innovator will experience three stages, namely knowledge, persuasion and finally making a decision. This process will provide experiences, challenges and consideration to the executor in assessing an innovation implemented. Green skills may be considered new in Malaysia; however, they have long been adopted in Japan and Korea.

Practice-based innovation needs strong support in terms of materials and parameters that are clear and measurable (Warford, 2010). In this case, researchers look at green skills as an idea or habit that can be put into practice with the support of teachers as the facilitators, who have a clear vision to cultivate the love for the environment. Innovation takes time but if done consistently, it will provide maximum effect and impact. This is in line with sustainable practices such as segregation of waste and 3R that can be a challenge in the beginning. However, if done consistently and are made into a routine, these practices will become a habit (Festus and Oggoeggbunam, 2012), (Licy et al. 2013), (Fahzy, 2014).

\section{Model of Sustainability}

Green skill is an innovation in education acting as a stepping stone to sustainable development. In planning an innovative green skill, a model of sustainable development was adapted from (Johnson et al. 2014). The process starts with determining the sustainability factor that influences an innovation, which is to implement the green skills elements as a measure to conserve the environment. This innovation should be consistent with the requirements, and there is a positive relationship between executor shareholders. The next step is to proceed with the sustainability action that involves five stages of development, which are assessment, planning, implementation, evaluation and re-evaluation, and modification, if necessary. Outcomes will come in two stages: results that can be seen immediately; and long-distal innovative results which consist of the elements of green skills applicable to preserve the environment. Green abilities (sustainable innovation) will be used and evaluated after the process of learning and teaching is completed (Outcomes) for viewing of immediate and long-term results. Distal outcomes also involve the Ministry of Education and Ministry of Technology, Energy and Water; they will observe if this innovation is workable and can be adopted. Innovation must have special features that produce services geared towards certain shareholders who meet specific criteria; (Johnson et al. 2014) in this present case the shareholder is the Ministry of Technology, Energy and Water, who plays a role in conserving and preserving the environment.

\section{Methodology}

This study adopted a qualitative approach, which utilized case studies. Sampling technique was used to interview respondents in focus groups. The collection of data from a focus group is more effective when the number is seven to twelve people, as it is easier to hold group discussions (Nagle and Williams, 2012). According to the list compiled by (Tersine and Ringgs, 1976) there are four criteria that can be used to identify a panel of experts: (1) have education related to a particular field; (2) have a good track record in a particular field; (3) have the leisure time to engage in the study until the end; and (4) are willing to spend some time in the study. Two other researchers, (Armstrong et al. 2000)and (Powel, 2003), stipulate a different set of criteria for the selection of the panel of experts: background, relevant work experience, willingness to contribute to the 
validity of the study, have a range of opinions, views and knowledge of the latest issues. Therefore, to collect a research sample, the researchers selected a total of seven teachers who are proficient in subject of life skills or design and technology. The sample selection criteria are as follows:

- An outstanding teacher in the subject of living skills or design and technology.

- Has a professional qualification in the field of living skills or design and technology

- Has been teaching the subject of living skills for at least five years or the subject of design and technology for three years; the subject of design and technology was introduced in the primary schools just 3 years ago.

Semi-structured interviews were used to obtain information from the research respondents. One of the advantages of a semi-structured interview is that researchers can pose additional questions to find out more details. The interviews for the focus group were conducted in four hours. The entire sessions of the interviews were recorded.

\section{Analysis of data}

Eight phases of the data collection process were carried out by researchers: the exploration phase of the study data; transcription phase; the coding phase; organizing phase; data exploration phase for the second interview; the second transcription phase; encoding process phase; and organizing phase. After an interview of the focus group was done, the recorded data were transcribed; then a code was created based on the themes identified. The process of assigning codes to the units of this paragraph makes it easier for researchers to identify the themes for each step and give clarification regarding the conduct (Yin, 2011). Subsequent to this, the researchers reviewed and organized the data by category and identified if any data were missing. Any missing data would be updated after the second interview was conducted. The transcribed data of the second interview were sent to the participants for review. The processes of encoding and data organization according to the identified five themes were executed again in detail.

As a measure to validate the data, the researchers requested the respondents to examine the raw data and confirm its accuracy. In addition, the respondents were also asked to comment on the accuracy and appropriateness of the categories and themes: were they supported by sufficient evidence or were the reports made realistic? This procedure adds credibility to the findings, providing an opportunity for participants to review and clarify the interpretation of the interview transcripts and verify the accuracy of the participants' ideas (Creswell, 2014). In addition, to ensure reliability of the data, the researchers used the method of audit trail. Through the audit trail, the researchers reported clearly how the data were collected, how the theme had been formed and decisions taken during the study. Examination of the colleagues was also carried out. This procedure provides written feedback and ideas, using the lens of outsiders to assess the results of the research (Maxwell, 2013). For this purpose, the researchers engaged the services of two lecturers who are experts in the field of technical and vocational education; two lecturers in the field of environment were also consulted because this research is related to environmental education. The researchers took into account the responses of the panels and made the necessary modifications and improvements.

\section{Findings}

The findings show that the respondents have presented some elements that can be incorporated in the teaching and learning of the subject of design and technology (D\&T), particularly on the topic of home economics (home science). These elements can be applied to develop innovation among students through the subject of D\&T. Several themes can be obtained from the findings, namely the management of solid waste, green practices and the concept of 3R-- Reduce, Reuse and Recycle. 


\section{Solid Waste Management}

The respondents suggest that the best way to carry out the practice of isolating remnants of organic and inorganic matters is through an environmentally sound manner as set out by Rie, Ziph and Shel.

"Isolate one place for food that is organic and inorganic. Inorganic food waste can be burned. The non-organic materials we dredge near the garden and bury in the hole, so it can flow and disposal can occur and at the same time it can be compost." (Rie)

"Separating the leftovers, provide bins of different colors, then students will know there aren't even recycling bins in the school." (Zif)

"Make sure there is no solid material that is thrown into the barrel. The rubbish will be separated as a value or item so students will be alert of that thing." (Shel)

\section{Green Practices}

The respondents also feel that some green practices can be practiced during cooking practical sessions such as conserving water and reducing the use of materials that cannot be recycled.

"Coconut husk can be used for washing dishes. Use the inner part to wash pots." (Shee)

"Save on the use of soap and water; wash the glasses first, so the water used for washing glasses can be used to rinse dishes, plates and food containers." (Zif)

"Look at the villagers. He used the example of banana pith. I asked: what is it? It can absorb oil, so before washing oily equipment, rub it first with banana pith." (Zif)

"So leftovers should not be discarded in the trash, we turn them into compost so it can be used as fertilizer." (Rie)

"We avoid the use of plastic, then, we can reuse plastic for hydroponics. And bring lunch from home, the food containers can be washed and reused." (Bak)

\section{R Concept}

The respondents also expressed that some 3R concepts can be practiced during the students' cooking practical activities, which are reuse, reduce and recycle.

\section{Reduse}

Shel believes "that for cooking practical, save water when cooking, washing and so on."Sha also provides the same opinion, "We have to implement it, before and after practice. Have to make sure not to waste, make sure to save."

\section{Reuse}

With regard to reuse, Bak believes students should practice it by using their own containers,

"We now want to implement green technology, students bring food containers from home and bring it to school, either to buy nasilemak, I would practice using my food container to buy nasilemak, then fill the NasiLemak (traditional Malay food) in it. That is green tech too right? Familiarize one-self to buy a safe container and to not use polystyrene." (Bak)

Zif and Rie also suggest reusing recycled materials, "Newspapers can be used to cover tables" and "Coconut husks can be used to wash pots that are greasy." Meanwhile, Shee gives another example such as in the wood work, surplus materials can be used for other uses, 
"So when sawing wood, there will be saw dust. Do not throw the dust as we can use it for something else. The saw dust can be used to moisten plants." (Shee)

\section{Recycle}

The respondents also suggest that students should be more creative in recycling used materials to produce other products as stated by Rie,

"I told the students to take old fabric and reuse them to make pot holders, then take old fabrics and tack them. We are teaching children to use things in the house and avoid expenditure. Those things can then be used again." (Rie).

Ziph also suggests the same thing, "Creating menus. Form colored cards into beautiful shapes, there are words that can be cut into pieces, arrange and paste it. I added to it by teaching students to create the menu by using recycled materials. Students really like doing things like these. It's creative.” Shee concurs with Ziph,

"For card decor, we recommend to decorate egg flowers and paste it on the card. Recycle; there is no need to buy new." (Shee)

\section{Discussion}

Solid waste is the cause of the high level of pollution and represents a great challenge to the environment (Licyet al. 2013), (Hanifahet al. 2012). Hence, the appropriate green-skill content that should be included first in the subject of design and technology is solid waste management, because the most effective way to reduce pollution is to adopt the separation management of solid waste at source before it is discarded or disposed of. Solid waste management is also recommended to be taught to students starting from the primary level by (Taylor et al. 2015). This finding is in line with what has been proposed by (Festus and Ogoeggbunam, 2012) and (DPSP, 2016) who suggest three things in an effective solid waste management: 1) Prevent waste generation; 2) Reduce waste at source; 3 ) Reuse of used goods and materials.

Thus, the schools must provide bins that label solid waste in accordance with appropriate and attractive colors as means to attract students to practice waste segregation in the right way. Students can adopt sustainable practices to conserve water, separate wastes and save electricity, as the findings of this study support those of (Wong and Wan, 2008), (Karpiak and Baril, 2008), (Ifegbesan, 2010). When the infrastructures in schools are adequate and conducive to sustainable development, the impact will be viewed holistically. This finding supports the suggestion by (Zuhair, 2015), which proposes that a study of infrastructure and related equipment for the implementation of green technology in the schools should be done; and the results and recommendations must be incorporated in the school curriculum. This will give students an avenue to practice green skills in the real world, which revolves around activities of their lives. Stakeholders or the underlying body of education should play a role in providing support such as in the form of equipment required, in addition to giving knowledge solely for the success of education related to sustainable environment in schools (Gorbonelet al. 2015), (AESA, 2014).

Green practices involving habits and behaviors that can reduce pollution are also suggested by the respondents. These green practices consist of mainly steps that can be taken to reduce the accumulation of solid waste and to reduce the harmful effects to the environment such as using natural resources and turning them into compost. Proper sanitation methods are also important as they are included in one of the titles of sustainable development studies based on project approach by (Stuhmcke, 2012) namely environmental friendly cleaning practice or environmental sensitive cleaning practices.

Hence, the practices of $3 \mathrm{R}$, reduce, reuse and recycle are also important elements in the teaching of environmental sustainability. Most of us are familiar with this topic, but practicing it or embracing it as a culture is another matter. Thus, these elements should be included in the teaching process as a step to instill the 
practices of 3R (Fahzy, 2014). Practical activities such as water and energy conservation in daily life are more effective than the awareness campaign of the environmental programs in schools. This idea is suggested by (Stuhmcke, 2012) and the recommended conservation practices such as saving electricity and water have become a culture of sustainability in schools.

Reusing and recycling of materials are two different practices but have the same goal, which is to reduce the generation of solid waste. Reuse is the practice of reusing items repeatedly, while recycling refers to putting something in a cycle. We recycle and segregate wastes; they are then distributed to organizations or factories that process them into new products for our use (DPSP, 2016). According to (Hasnahet al. 2012), reusing items by improving the products will benefit the public by selling reusable materials, and this process can help reduce waste and protect the environment. The $3 \mathrm{R}$ practices are elements already included in the existing teaching modules or guidelines of sustainable development in overseas countries; for example,Teachingthe 3 Rs: Reduce, Reuse, Recycle Keystage 3 in Australia (www.eco-schoolsni.org), and Resource Smart School in Ireland (resourcesmart.vic.gov.au).

The above-mentioned details are elements of green skills that need to be addressed and can be incorporated into the skill-oriented subjects such as design and technology (D\&T), so that students can think about the environment and master these sustainability practices. This can give a positive impact to the environment and create a culture of conservation and love for nature (Festus and Ogoeggbunam, 2012), (Licyet al. 2013), (Hasnahet al. 2012).

\section{Conclusions}

There is a need for green skills to be included in the subject of D\&T in primary schools because the elements of these skills support the principle of environmental sustainability. This is an innovation that should be added to the curriculum as a skill. Green skills that can be imparted to students include the following: the right solid waste management practices, green practices and practices of 3R-- Reduce, Reuse and Recycle. As we know, the $3 \mathrm{R}$ method is still very much in demand by members of the global community (Hasnahet al.2012). The content can also be used as a guide for planning the construction of teaching modules and curriculum development.

\section{Acknowledgements}

The author gratefully acknowledges the Ministry of Higher Education of Malaysia for the funding of the project FRGS (Fundamental Research Grant Scheme), 2015-0166-107-02 (FRGS/1/2015/SS109/UPSI/03/13). The author also acknowledges the constructive comments received by the anonymous reviewers.

\section{References}

Arasinah, K. Ramlee, M.,Waliza, M.A.W., and BushraLamuna, I., 2016, Green Skills as an Added-Value Element in Producing Competent, Int. Journal of Engineering Research and Application, vol. 6(11) pp.12-21.

Armstrong, A.E. Parsons, S. and Barker, P.J., 2000, An inquiry into moral virtues, especially compassion, in psychiatric nurses: Findings from a Delphi study, Journal of Psychiatric and Mental Health Nursing, 7(4), pp. 297-306.

Australian Education for Sustainability Alliance [AESA], Education for sustainability and the Australian Curriculum Project: Final report for Research Phases 1 to 3, Melbourne, VIC, Australia, Date of accessed: 16/05/2015. http://aries.mq.edu.au/publications/other/Education/EfS-in-Aust-Curriculum.pdf

Carbonel, L.G., Adora, M.B., and Agbisit, I.C., 2015, Global Environmental Issues Awareness and The Perceived Remedial Measures, International Journal of Advanced Research in Management and Social Sciences, vol. 4(11), pp. 148-161.

Cedefop, Green skills and environmental awareness in vocational education and training, European Centre for the Development of Vocational Training, Luxembourg, Date of accessed: 12/01/2015. http://www.cedefop.europa.eu/files/5524_e n.pdf 
Cedefop, Greener Skills and Jobs. OECD Green Growth Studies. OECD Publishing. Date of accessed: 5/05/2015. http://dx.doi.org/10.1787/9789264208704-

Creswell, J.W., 2014. Educational Research: Planning, Conducting and Evaluating Quantitative and Qualitative Research (4th ed), New Jersey: Pearson Education Inc.

DasarPengurusanSisaPepejal Negara, [DSKP], In Malay, Date of accessed 24/04/2016. http://jpspn.kpkt.gov.my/.

Dokumen Standard KurikulumdanPantaksiran RBT Tahun 5, [DSKP], 2014, BahagianPendidikanKurikulum, KementerianPendidikan Malaysia. In Malay.

Fahzy, A. R., 2014, Reduce, Reuse, Recycle: Alternatives for Waste Management, Unpublished, in Extension Family Resource Management Specialist, Department of Extension Family and Consumer Sciences, New Mexico State University.

Festus, M.O., and Ogoeggbunam, O.B., 2012, Imperatives of environmental education and awareness,Educational Sciences, pp. 254-258.

Hanifah, M., 2014, Kesedaran dan Komitmen Pendidikan Pembangunan Lestari Dalam Komuniti Sekolah Menerusi Program Sekolah Lestari di Malaysia,In Malay, PhD Dissertation, Perak, Universiti Pendidikan Sultan Idris.

Hanifah, M., Yazid, S., Mohmadisa, H., and Nasir, N., 2016, Model Development on Awareness of Education for Sustainable Schools Development in Malaysia, International Journal of Geografi. vol. 48 (1), pp.37-46.

Hasnah, A., Dody, D., Noraziah, A.,Maznah, I., andSarifah, Y., 2012, Masyarakat dan amalan pengurusan sisa pepejal ke arah kelestarian komuniti: Kes isi rumah wanita di Bandar Baru Bangi, Malaysia. In Malay, GeografiaMalaysia Journal of Society and Space, vol.8(54), pp. 64-75.

Ifegbesan, A., 2010, Exploring Secondary School Students' Understanding and Practices of Waste Management in Ogun State, Nigeria, International Journal of Environmental and Science Education, vol. 5(2),pp. 201-215.

Jabatan Alam Sekitar, Kementerian Pelajaran Malaysia, Institut Alam Sekitar dan Pembangunan (LESTARI), Asas pembentukan Sekolah Lestari Anugerah Alam Sekitar, (Ed.ke-3), 2012, In Malay, Jabatan Alam Sekitar, Putrajaya,

Jamilah, A., and Hasrina, A., 2011, Pengetahuan, SikapdanAmalanMasyarakat Malaysia TerhadapIsuAlamSekitar," unpublished, In Malay, UniversitiKebangsaan Malaysia.

Johnson, K., Hays, C., Center, H., and Daley, C., 2014, Building capacity and sustainable prevention innovations: a sustainability, Evaluation and Program Planning Research, vol. 7, pp. 135-149.

Karpiak, C.P., and Baril, G.L., 2008, Moral reasoning and concern for the environment, Journal of Environmental Psychology, vol. 28(3),pp. 203-208.

Kementerian Tenaga, Teknologidan Air, In Malay, Date of accessed 16/06/2016. http://www.kettha.gov.my/portal/index.php.

Licy, C., Vivek, R., Saritha, K., Anies, T,. and Josphina, C., 2013, Awareness, Attitude and Practise of Scholl Students toward Household Waste Management, Journal of Environment, pp. 147-150.

Maxwell, J.A., 2013, Qualitative Research Design: An Interactive Approach, Thousand Oaks: Sage.

McDonald, G., Condon, L., andRiordan, M., 2012, The Australian Green Skills Agreement:Policy and Industry Context, Institutional Response and Green Skills Delivery," TAFE Directors Australia, Broadway, Australia.

Meenakshi, S., and R. Leela, R., Environmentally Sustainable Consumption: A Review and Agenda for Future, Research in Global Journal of Finance and Management, 6(4), pp. 367-374.

Mohd Zuhair, A.Z., 2015, Tahap Kesedaran Teknologi hijau dalam Kalangan Guru-guru Kejuruteraan Zon Utara, In Malay. Master Thesis, Universiti Tun Hessein Onn. Malaysia.

Nagle, B., and Williams, N., 2012. Methodology Brief: Introduction to Focus Groups. Center for Assessment, Planning and Accountability. Date of accessed 16/07/2015. http://www.uncfsp.org/projects/userfiles/File/FocusGroupBrief.pdf

Pavlova, M., and Huang, C.L., 2013, Advancing Employability and Green Skills Development: Values Education in TVET, the Case of the People's Republic of China,Skills development for inclusive and sustainable growth in developing Asia- Pacific Technical and Vocational Education and Training. Issues, Concerns and Prospects, vol.18, pp. 327-343. Date of accessed 15/06/2015. http://download.springer.com/static/pdf/487 /chp\%253A10.1007\%252F978-94-007-5937 
Powel, C., 2003, The Delphi technique. Myths and realities, Journal of Advanced Nursing, vol.19(6), pp.12211225.

Rogers, E.M., 2013, Diffusion of Innovations (5th ed.), New York: Free Press.

Saravanan, R.H., and Ahmad, M., 2013, Amalan Penggunaan Lestari dalam kalangan pelajar tingkatan empat di daerah Kluang Johor, In Malay, International Conference Geografi Dan Alam Sekitar Kali Ke-4, Malaysia, pp. 169-180,

Shahrom, M.Z.,Noor Ezlin, A.B., Fatihah, S., Othman,J and Hassan,B., 2015, Pendidikan Alam Sekitar: Bagaimana usaha-usaha dilakukan dalam Proses Pengajaran dan Pembelajaran, unpublished, In Malay, Bangi Selangor, UKM.

Sharifah Zarina, S. Z., 2014, Pengetahuan Alam Sekitar Dalam Pendidikan Sains Sekolah Rendah Asas Pembangunan Lestari, In Malay, Jurnal dalam Pembangunan Lestari Di Malaysia, vol. 7, pp. 261-277.

Siti Nor Syazwani, S.,Mohd Safarin, N., and Muhammad Sukri, S., 2014, Integrasi Teknologi Hijau Dalam Kurikulum Pendidikan Teknik Dan Vokasional (PTV), In Malay, Journal of Technical, Vocational \& Engineering Education, vol. 5, pp. 11-19.

Siti Rohani, J., 2013, Kesedaran Teknologi Hijau Dalam Kalangan Warga Universiti Tun Hussein Onn,In Malay, Master Thesis, Universiti Tun Hussein Onn.

Sola, A.O., 2014, Environmental education and public awareness, Journal of Educational and Social Research, 4(3), pp. 333-337.

Strietska-Ilina, O., Hofmann, C., Haro, M.D., and Jeon, S., 2012, Skills for green jobs: A global view, International Labour Office, Geneva,Date of accessed 11/02/2016. www.ilo.org/publns

Stuhmcke, S. M., 2012. Children As Change Agents For Suistanaibility, An Action Reserach Case Study In a Kindergarden, PhD Dissertation, Faculty of Education. Queensland University of Technology.

Taylor, N., Quinn, F. and Eames, C., 2015, Educating for Sustainability in Primary Schools Teaching for the Future, Sense Publishers.

Teaching the 3 Rs: Reduce, Reuse, Recycle Keystage 3.Date of accesed 17/05/2015. http://gcpcenvis.nic.in/Kids-Student/SV_RS_Reduce_Reuse_Recycle1.pdf

Teoh, E.S., 2016, An Evaluation of Environmental Education in Selected Primary Schools in Pahang, Malaysia, $\mathrm{PhD}$ Dissertation, Perak, Universiti Pendidikan Sultan Idris.

Tersine, R.J., and Ringgs, W.E., 1979, The Delphi technique: A long range planning tool, Business Horizons, pp. 51-56.

The Green Schools Resource Guide A Practical Resource for Planning and Building Green Schools in Ontario, Date of accessed 13/05/2015. http://www.edu.gov.on.ca/eng/policyfunding/GreenSchools_Guide.pdf

UNEVOC, International Centre for Technical and Vocational Education and Training. Date of accessed 12/06/2016. http://www.unevoc.unesco.org/International Conference on Sustainable Development.

Yin, R.K., Qualitative Research from Start to Finish, New York: The Guilford Press.

Warford, M.K., 2010, Testing a Diffusion of Innovations in Education Model (DIEM), The Innovation Journal: The Public Sector Innovation Journal, vol. 10(3), pp. 7-17.

Wong, T.K., and Wan, S.P., 2018, Environmental awareness and behavior in Hong Kong: A decade of development. TASPPA Partnership with 